\title{
Phytocomponent $p$-hydroxycinnamic acid stimulates mineralization in osteoblastic MC3T3-E1 cells
}

\author{
MASAYOSHI YAMAGUCHI ${ }^{1}$, YING LING LAI, SATOSHI UCHIYAMA and TAEKO NAKAGAWA \\ Laboratory of Endocrinology and Molecular Metabolism, Graduate School of Nutritional Sciences, \\ University of Shizuoka, 52-1 Yada, Shizuoka 422-8526, Japan
}

Received December 27, 2007; Accepted March 17, 2008

DOI: 10.3892/ijmm_00000021

\begin{abstract}
Phytocomponent $p$-hydroxycinnamic acid (HCA) has been shown to have stimulatory effects on bone calcification and inhibitory effects on bone resorption in rat femoral tissues in vitro. Whether HCA has a stimulatory effect on mineralization in osteoblastic cells is unknown. This study was undertaken to determine the effect of HCA on mineralization in osteoblastic MC3T3-E1 cells in vitro. Cells were cultured for $72 \mathrm{~h}$ in a minimum essential medium ( $\alpha$-MEM) containing $10 \%$ fetal bovine serum (FBS), and the cells with subconfluency were changed to a medium containing either vehicle or HCA $\left(10^{-7}-10^{-5} \mathrm{M}\right)$ without FBS. Culture with HCA $\left(10^{-7}-10^{-5} \mathrm{M}\right)$ did not have a significant effect on cell proliferation and cell death. Deoxyribonucleic acid (DNA) content in osteoblastic cells was significantly increased after culture with HCA $\left(10^{-6}\right.$ or $\left.10^{-5} \mathrm{M}\right)$ for 48 or $72 \mathrm{~h}$. Alkaline phosphatase activity in osteoblastic cells was significantly increased after culture with HCA $\left(10^{-7}-10^{-5} \mathrm{M}\right)$ for 24,48 , or $72 \mathrm{~h}$. The results with Alizarin red staining for calcium showed that mineralization was significantly stimulated after culture with HCA $\left(10^{-8}-10^{-5} \mathrm{M}\right)$ for 7,14 , or 21 days. This study demonstrates that HCA has stimulatory effects on mineralization in osteoblastic MC3T3-E1 cells.
\end{abstract}

\section{Introduction}

Osteoporosis with a decrease in bone mass is widely recognized as a major public health problem $(1,2)$. The most dramatic expression of this disease is represented by fractures of the proximal femur. Deficiency of nutrients is after observed in the elderly, and it appears to be more severe in patients

Correspondence to: Dr Masayoshi Yamaguchi, ${ }^{1}$ Present address: Division of Endocrinology and Metabolism and Lipids, Department of Medicine, Emory University School of Medicine, 1639 Pierce Drive, 1305 WMRB, Atlanta, GA 30322-0001, USA

E-mail: yamamasa1155@yahoo.co.jp

Key words: $p$-hydroxycinnamic acid, mineralization, bone formation, osteoblast with fracture than in the general aging population $(3,4)$. Pharmacological and nutritional factors are needed to prevent bone loss with increasing age (5-7). Bone loss may be due to decreased bone formation and increased bone resorption.

Cinnamic acid is present in many plants. $p$-Hydroxycinnamic acid (HCA) is an intermediate metabolic substance in plants, and it is synthesized from thyrosine. HCA is found in turnip tops, corn bran, and oregano (8-10). Among cinnamic acid and other related compounds (including HCA, ferulic acid, caffeic acid, and 3,4-dimethoxycinnamic acid), HCA has unique anabolic effects on bone components (11). HCA has been found to have stimulatory effects on bone formation and inhibitory effects on bone resorption in rat femoral tissues in vitro (11). HCA has potent inhibitory effects on osteoclast-like cell formation in mouse bone marrow cultures in vitro (12). The intake of HCA is found to have anabolic effects on bone components in the femoral tissues of normal rats (13), inhibitory effects on bone loss in diabetic rats administered with streptozotocin (14), and preventive effect on bone loss in ovariectomized rats (15). HCA may have a role in the prevention of osteoporosis with aging.

Whether HCA has anabolic effects on osteoblastic cells that are involved in bone formation and mineralization has not been clarified. This study was undertaken to determine the effect of HCA in osteoblastic MC3T3-E1 cells in vitro. We found that HCA stimulates mineralization in osteoblastic cells in vitro.

\section{Materials and methods}

Chemicals. $\alpha$-minimal essential medium ( $\alpha$-MEM) and penicillin-streptomycin $(5,000 \mathrm{U} / \mathrm{ml}$ penicillin; $5,000 \mu \mathrm{g} / \mathrm{ml}$ streptomycin) were obtained from Gibco Laboratories. Fetal bovine serum (FBS) was obtained from Bioproducts, Inc. $p$-Hydroxycinnamic acid (HCA) and alizarin red $\mathrm{S}$ was purchased from Sigma (St. Louis, MO, USA). Other chemicals were of reagent grade and were obtained from Wako Pure Chemical Industries (Osaka, Japan). All water used were glass distilled.

Cell culture. Osteoblastic MC3T3-E1 cells were cultured at $37^{\circ} \mathrm{C}$ in a $\mathrm{CO}_{2}$ incubator in plastic dishes containing $\alpha$-MEM supplemented with $10 \%$ FBS. They were subcultured every 3 days using $0.2 \%$ trypsin plus $0.02 \%$ EDTA in $\mathrm{Ca}^{2+} / \mathrm{Mg}^{2+}$-free 


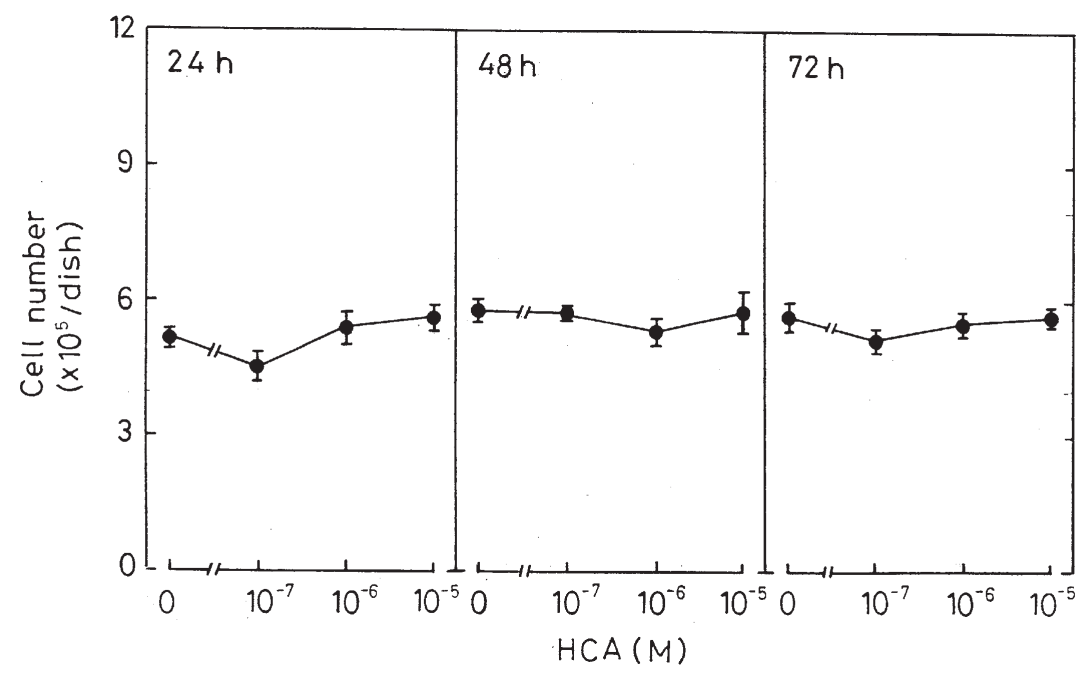

Figure 1. Effect of $p$-hydroxycinnamic acid (HCA) on cell death of osteoblastic MC3T3-E1 cells. Osteoblastic cells (1x10 ${ }^{5}$ cells) were cultured for 72 h in a medium containing $10 \%$ FBS. Cells with subconfluency were changed to a medium without FBS in the presence or absence of $\mathrm{HCA}\left(10^{-7}-10^{-5} \mathrm{M}\right)$. After medium change, cells were cultured for 24,48 , or $72 \mathrm{~h}$. After trypsinization of the cells in each cultured dish, cells were collected and counted. Each value is the mean \pm SEM of six cultures. Data were not significant as compared with the value between control and HCA treatment.

phosphate-buffered saline (PBS). For experiments, about $1.0 \times 10^{5}$ cells per dish were cultured for $72 \mathrm{~h}$ to obtain subconfluent monolayers in 35-mm plastic containing $2 \mathrm{ml} \alpha$-MEM with $10 \%$ FBS. After the cells were rinsed with PBS, the medium was exchanged for medium without FBS containing either vehicle or HCA $\left(10^{-7}-10^{-5} \mathrm{M}\right)$, and the cells were cultured further for 7-21 days. Cell viability was estimated by staining with trypan blue.

Cell counting. After trypsinization of the cells in each culture dish using $\mathrm{Ca}^{2+} / \mathrm{Mg}^{2+}$-free PBS containing $0.2 \%$ trypsin and $0.02 \%$ EDTA for $2 \mathrm{~min}$ at $37^{\circ} \mathrm{C}$, cells were collected and wash-centrifuged in a phosphate-buffer saline (PBS) solution at $100 \mathrm{~g}$ for $5 \mathrm{~min}$. The cells were resuspended in a $0.5 \mathrm{ml}$ PBS solution, and an aliquot was stained with eosin. The cells were counted under a microscope using a hemacytometer plate. For each dish, we took the average of two counts.

Biochemical analysis. To measure DNA content in the cells, the cells were detached using $0.2 \%$ trypsin plus $0.02 \%$ EDTA in $\mathrm{Ca}^{2+} / \mathrm{Mg}^{2+} /$ free PBS and washed with PBS. The cells were shaken with $2.0 \mathrm{ml}$ of ice-cold $0.1 \mathrm{~N} \mathrm{NaOH}$ solution for $6 \mathrm{~h}$ after disruption (16). After alkali extraction, the samples were centrifuged at $10,000 \mathrm{~g}$ for $5 \mathrm{~min}$, and the supernatant was collected. DNA content in the supernatant was determined using the method of Ceriotti (17) and expressed as the amount of DNA $(\mu \mathrm{g})$ per dish.

To determine the protein concentration in osteoblastic cells, the cells were washed three times with PBS, scraped into $0.5 \mathrm{ml}$ of ice-cold $0.25 \mathrm{M}$ sucrose solution, and disrupted for $30 \mathrm{sec}$ with an ultrasonic device. Protein concentration in the cell homogenate was determined using the method of Lowry et al (18) and expressed as the amount of protein $(\mu \mathrm{g})$ per dish.

To assay alkaline phosphatase activity in the cells after appropriate treatment periods, the cells were washed three times with PBS, scraped into $0.5 \mathrm{ml}$ of ice-cold $0.25 \mathrm{M}$ sucrose solution, and disrupted for $30 \mathrm{sec}$ with an ultrasonic device. The supernatant, centrifuged at $600 \mathrm{~g}$ for $5 \mathrm{~min}$, was used to measure enzyme activity. The enzyme assay described below was carried out under optimal conditions. Alkaline phosphatase activity was determined using the method of Walter and Schutt (19). The enzyme activity was expressed as nanomoles of p-nitrophenol liberated per minute per milligram of protein.

Alizarin red staining. Osteoblastic MC3T3-E1 cells $\left(2.5 \times 10^{5}\right.$ cells) were cultured for $72 \mathrm{~h}$ in $\alpha$-MEM containing $10 \%$ FBS. Cells with subconfluency were changed to Dulbecco's modified essential medium (DMEM) containing ascorbic acid $(100 \mu \mathrm{g} / \mathrm{ml})$ and $4 \mathrm{mM} \beta$-glycerophosphate in the presence or absence of HCA $\left(10^{-8}\right.$ or $\left.10^{-5} \mathrm{M}\right)$ with $10 \%$ FBS. After medium change, cells were cultured for 7, 14, or 21 days. The medium was changed with every 3 days. At each timepoint, cells were rinsed with PBS, and fixed on ice with $70 \%$ ethanol for $15 \mathrm{~min}$ for alizarin red staining of calcium (20). The Alizarin red solution ( $40 \mathrm{mM}, \mathrm{pH} 4.2)$ was filtered through Whatman paper and applied to the fixed wells for $30 \mathrm{~min}$ at room temperature. Non-specific staining was removed by several washes in water.

Statistical analysis. Data are expressed as the mean \pm SEM. Statistical differences were analyzed using Student's t-test. P-values $<0.05$ were considered to indicate statistically significant differences. Also, we used an ANOVA multiple comparison test to compare the treatment groups.

\section{Results}

Effect of HCA on proliferation of osteoblastic MC3T3-E1 cells. The effect of HCA on proliferation of osteoblastic MC3T3-E1 cells reaching subconfluent monolayer was examined. Osteoblastic cells were cultured for $72 \mathrm{~h}$ in a medium containing $10 \%$ FBS in the presence or absence of 


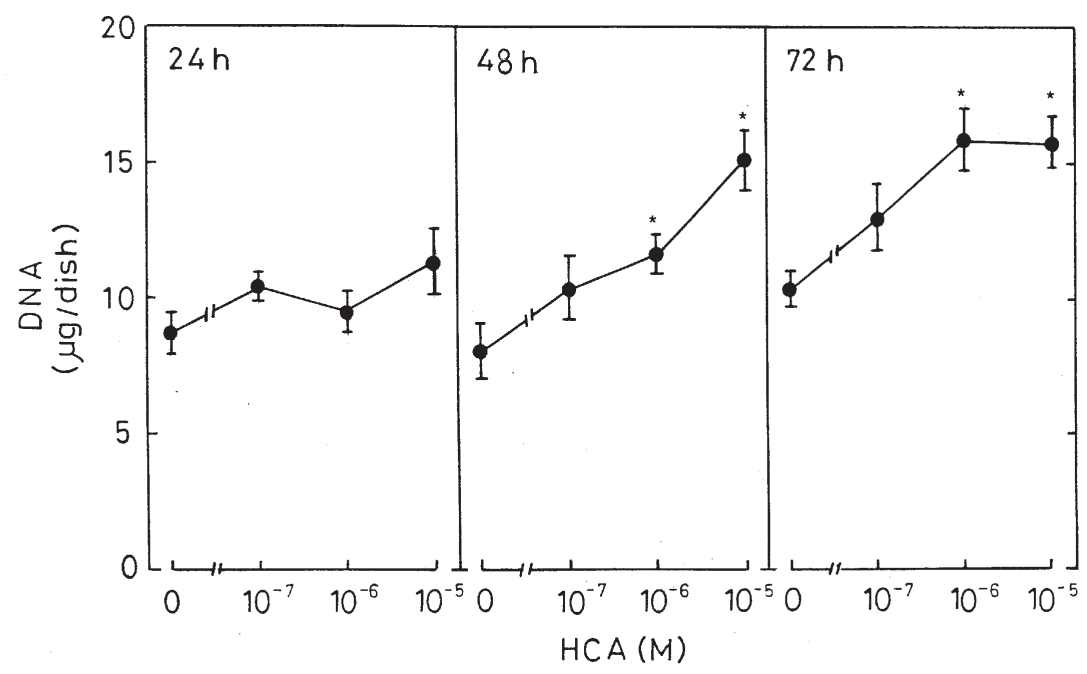

Figure 2. Effect of $p$-hydroxycinnamic acid (HCA) on DNA content in osteoblastic MC3T3-E1 cells. Osteoblastic cells were cultured for $72 \mathrm{~h}$ in a medium containing 10\% FBS. After culture, the medium was changed, then HCA $\left(10^{-7}-10^{-5} \mathrm{M}\right)$ was added in the culture medium without FBS, and the cells were cultured for an additional 24, 48, or $72 \mathrm{~h}$. Cells washed with PBS and scraped to determine DNA content. Each value is the mean \pm SEM of six cultures. ${ }^{*} \mathrm{P}<0.01$ compared with the control (none) value.

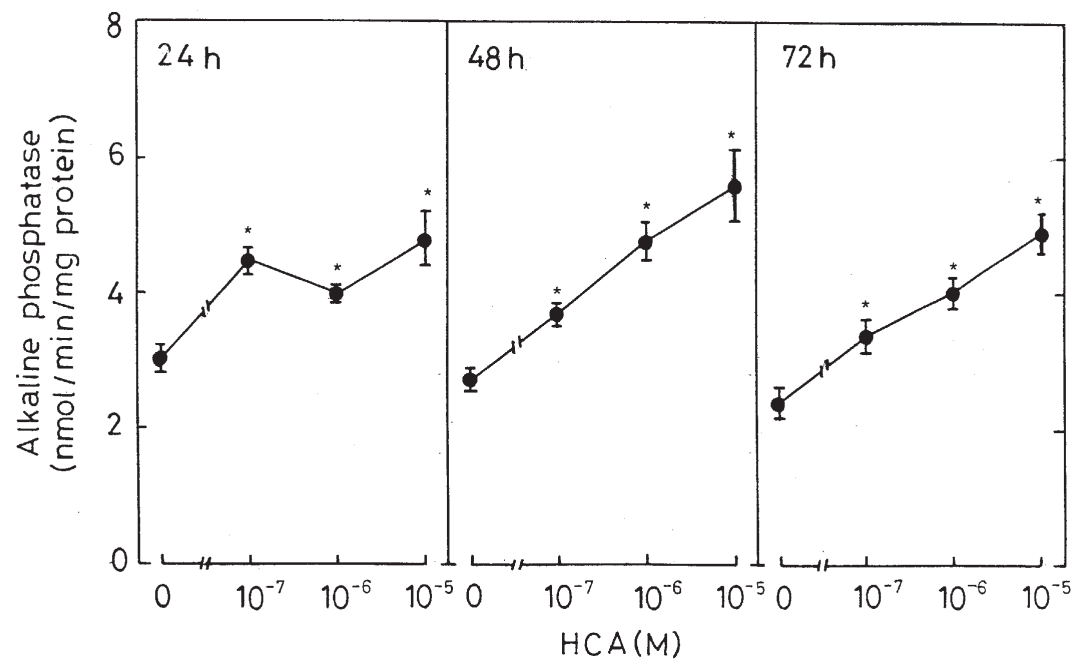

Figure 3. Effect of $p$-hydroxycinnamic acid (HCA) on alkaline phosphatase activity in osteoblastic MC3T3-E1 cells. Osteoblastic cells were cultured for $72 \mathrm{~h}$ in a medium containing $10 \%$ FBS. After culture, the medium was changed, then HCA $\left(10^{-7}-10^{-5} \mathrm{M}\right)$ was added in the culture medium without FBS, and the cells were cultured for an additional 24,48 , or $72 \mathrm{~h}$. Cells washed with PBS and scraped to determine DNA content. Each value is the mean \pm SEM of six cultures. ${ }^{*} \mathrm{P}<0.01$ compared with the control (none) value.

HCA $\left(10^{-7}-10^{-5} \mathrm{M}\right)$. The proliferation of osteoblastic cells was progressively increased with culture of $72 \mathrm{~h}$ to reach confluent monolayers. This increase was not significantly changed in the presence of HCA $\left(10^{-7}-10^{-5} \mathrm{M}\right.$ ) (data not shown). The effect of HCA $\left(10^{-7}-10^{-5} \mathrm{M}\right)$ on cell number was not observed when the cells with subconfluency were cultured for 24,48 , or $72 \mathrm{~h}$ in the absence of $10 \%$ FBS (Fig. 1).

Effect of HCA on biochemical components in osteoblastic MC3T3-E1 cells. Osteoblastic cells were cultured for $72 \mathrm{~h}$ in a medium containing $10 \%$ FBS. Cells with subconfluency were cultured for 24,48 , or $72 \mathrm{~h}$ in a medium containing HCA $\left(10^{-7}-10^{-5} \mathrm{M}\right)$ without FBS. The change in DNA content or alkaline phosphatase activity in osteoblastic cells was examined. DNA content in osteoblastic cells was significantly increased after culture with HCA $\left(10^{-6}\right.$ or $\left.10^{-5} \mathrm{M}\right)$ for 48 or $72 \mathrm{~h}$ (Fig. 2). Alkaline phosphatase activity in osteoblastic cells was significantly increased after culture with HCA $\left(10^{-7}-10^{-5} \mathrm{M}\right)$ for 24,48 , or $72 \mathrm{~h}$ (Fig. 3).

Effect of HCA on mineralization in osteoblastic cells. Osteoblastic cells with subconfluency were cultured for 7,14 , or 21 days in a medium containing either vehicle or HCA $\left(10^{-8}\right.$ $10^{-5} \mathrm{M}$ ) to examine the mineralization (Fig. 4). The results with Alizarin red staining for calcium showed that mineralization was significantly stimulated in the presence of HCA $\left(10^{-8}-10^{-5} \mathrm{M}\right)$. The enhancement of mineralization was observed after 7 days of culture. The effect was markedly enhanced after 21 -days of culture with HCA $\left(10^{-6}\right.$ or $\left.10^{-5} \mathrm{M}\right)$. 


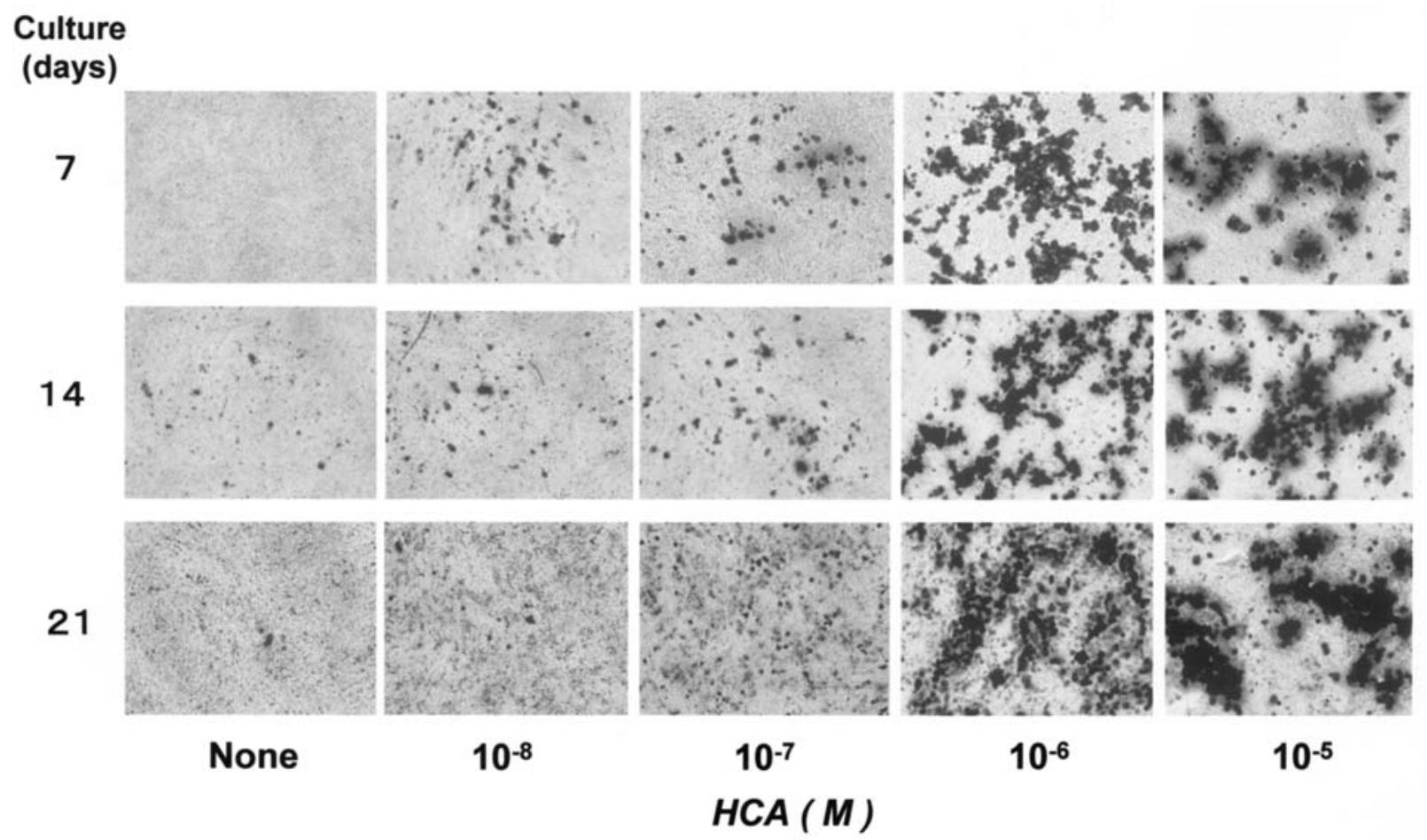

Figure 4. Effect of $p$-hydroxycinnamic acid (HCA) on mineralization in osteoblastic MC3T3-E1 cells. Osteoblastic cells $\left(2.5 \times 10^{5}\right.$ cells) were cultured for $72 \mathrm{~h}$ in a medium containing $10 \%$ FBS. Cells with subconfluency were changed to a medium with $10 \%$ FBS in the presence or absence of $\mathrm{HCA}\left(10^{-8}-10^{-5} \mathrm{M}\right)$. After medium change, cells were cultured for 7, 14, or 21 days. Cells were washed with PBS and stained with Alizarin red stain. The figure shows one of four experiments with separate culture.

\section{Discussion}

Phytocomponent HCA has been shown to have stimulatory effects on bone formation and inhibitory effects on bone resorption in rat femoral tissues in vitro (11). HCA inhibits osteoclastogenesis in mouse marrow culture in vitro (12), suggesting that the compound can inhibit osteoclastic bone resorption. Whether HCA has anabolic effects on osteoblastic cells in vitro was examined. HCA was found to have stimulatory effects on mineralization in osteoblastic MC3T3-E1 cells in vitro.

HCA did not have a significant effect on cell proliferation of osteoblastic cells in reaching subconfluent monolayers (data not shown). Also, the number of osteoblastic cells with subconfluency was not significantly changed after culture with HCA, indicating that the compound does not induce cell death.

Culture with HCA caused a significant increase in DNA content in osteoblastic cells. The effect of HCA in increasing DNA content in osteoblastic cells was seen in the absence of FBS. It is speculated that HCA has a stimulatory effect on DNA synthesis in osteoblastic cells.

Alkaline phosphatase is involved in mineralization in osteoblastic cells (21). The enzyme activity in osteoblastic cells was significantly increased after culture with HCA. It is assumed that HCA stimulates cell differentiation in osteoblastic cells.

The results of Alizarin red stain showed that the prolonged culture with HCA markedly stimulates mineralization in osteoblastic cells. This finding may support the view that culture with $\mathrm{HCA}$ induces the differentiation of osteoblastic cells and stimulates mineralization in the cells. HCA caused a significant increase in calcium content in rat femoral tissue culture in vitro (11). Thus, HCA was demonstrated to have stimulatory effects on osteoblastic mineralization.

In conclusion, it has been demonstrated that culture with HCA stimulates mineralization in osteoblastic MC3T3-E1 cells in vitro.

\section{References}

1. Cooper C and Melton J III: Epidemiology of osteoporosis. Trends Endocrinol Metab 3: 224-229, 1992.

2. Cummings SR, Kelsey JL, Nevitt MC and O'Dowd KJ: Epidemiology of osteoporosis and osteoporotic fracture. Epidemiol Rev 7: 178-199, 1985.

3. Young GA, Chem C and Hill GL: Assessment of protein-caloric malnutrition in surgical patients from plasma proteins and anthropometric measurements. Am J Clin Nutr 31: 429-435, 1978.

4. Older NWJ, Delyth E and Dickerson JWT: A nutrient survey in elderly women with femoral neck fracture. Br J Surg 67: 884-886, 1982.

5. Bonjour J-P, Schurch M-A and Rozzori R: Nutritional aspects of hip fractures. Bone 18: 1395-1445, 1996.

6. Yamaguchi M: Isoflavone and bone metabolism; its cellular mechanism and preventive role in bone loss. J Health Sci 48 : 209-222, 2002.

7. Yamaguchi M: Regulatory mechanism of food factors in bone metabolism and prevention of osteoporosis. Yakugaku Zasshi 126: 1117-1137, 2006.

8. Romani A, Vignolini P, Isolani L, Ieri F and Heimler D: HPLCDAD/MS characterization of flavonoids and hydroxycinnamic derivatives in turnip tops (Brassica rapa L, Subsp, Sylvestris L.). J Agric Food Chem 22: 1342-1346, 2006.

9. Zhao Z, Egashira Y and Sanada H: Phenolic antioxidants richly contained in corn bran are slightly bioavailable in rats. J Agric Food Chem 15: 5030-5035, 2005. 
10. McCue P, Vattem D and Shetty K: Inhibitory effect of clonal oregano extracts against porcine pancreatic amylase in vitro. Asia Pac J Clin Nutr 13: 401-408, 2004.

11. Lai YL and Yamaguchi M: Phytocomponent $p$-hydroxycinnamic acid stimulates bone formation and inhibits bone resorption in rat femoral tissues in vitro. Mol Cell Biochem 292: 45-52, 2006.

12. Lai YL and Yamaguchi M: Phytocomponent $p$-hydroxycinnamic acid inhibits osteoclast-like cell formation in mouse bone marrow cultures. Int J Mol Med 19: 123-128, 2007.

13. Lai YL and Yamaguchi M: Oral administration of phytocomponent $p$-hydroxycinnamic acid has anabolic effects on bone calcification in femoral tissues of rats in vivo. J Health Sci 52: 308-312, 2006.

14. Yamaguchi M, Uchiyama S and Lai YL: Oral administration of phytocomponent $p$-hydroxycinnamic acid has a preventive effect on bone loss in streptozotocin-induced diabetic rats. Int J Mol Med 19: 803-807, 2007.

15. Yamaguchi M, Lai YL, Uchiyama S and Nakagawa T: Oral administration of phytocomponent $p$-hydroxycinnamic acid prevents bone loss in ovariectomized rats. Mol Cell Biochem
311: 31-36, 2008.

16. Flanagan B and Nichols G Jr: Metabolic studies of bone in vitro. IV. Collagen biosynthesis by surviving bone fragments in vitro. J Biol Chem 237: 3687-3692, 1962.

17. Ceriotti G: Determination of nucleic acids in animal tissues. J Biol Chem 214: 39-77, 1955.

18. Lowry OH, Rosebrough NJ, Farr AL and Randall RJ: Protein measurement with the Folin phenol reagent. J Biol Chem 193: 265-275, 1951.

19. Walter K and Schutt C: Acid and alkaline phosphatase in serum. In: Methods of Enzymatic Analysis. Vol. 1-2. Bergmeyer HV (ed). Academic Press, New York, pp856-860, 1965.

20. Kamiya N, Jihho A, Kimata K, Damsky C, Shimizu K and Watanabe H: Establishment of a novel chondrocytic cell line N1511 derived from p53-null mice. J Bone Miner Res 17: 1832-1842, 2002.

21. Majeska RJ and Wuthier RE: Studies on matrix vesicles isolated from chick epiphyseal cartilage. Association of pyrophosphatase and ATPase activities with alkaline phosphatase. Biochim Biophys Acta 391: 51-60, 1975. 